\title{
A history of the use of the concept of parental alienation in the Australian family law system: Contradictions, collisions and their consequences
}

Zoe Rathus

Griffith Law School, Griffith University, Brisbane, Australia. ${ }^{1}$

\section{Abstract}

This paper presents insights into the history and current deployment of the concept of parental alienation in the Australian family law system. The paper begins in 1989, the first time an article on parental alienation syndrome was published in an Australian law journal. It then traces aspects of the socio-legal and social science research, gender politics, law reform and jurisprudence of the following 30 years, paying attention to moments of significant change. The impacts of major amendments that emphasise the desirability of post-separation shared parenting outcomes in 1996 and 2006 are specifically considered. More recently, in 2012, reforms intended to improve the family law system's response to domestic and family violence were introduced. The history reveals an irreconcilable tension between the 'benefit' of 'meaningful' post-separation parent-child relationships and the protection of children from harm. When mothers' allegations of violence in the family are disbelieved, minimised or dismissed, they are transformed from victims of abuse into perpetrators of abuse - alienators of children from their fathers. Their actions and attitudes collide with the shared parenting philosophy. This is arguably an inescapable consequence of a family law system that struggles to deal effectively with family violence in the context of a strong shared parenting regime.

Key words: parental alienation; family violence; child abuse; family law.

\footnotetext{
${ }^{1}$ Zoe Rathus. Email: z.rathus@griffith.edu.au.
} 


\section{Introduction}

Social science research and the behavioural sciences are deeply entwined with the contemporary family law system in Australia and elsewhere (eg. Rhoades 2002; Robertson and Broadhurst 2019). These sciences inform family law policy in parenting cases ${ }^{\mathrm{i}}$ and have become embedded in legislation and procedure. ${ }^{\text {ii }}$ They also perform direct roles in the courtroom through expert reports and oral testimony. Although social and behavourial science knowledge has undoubtedly contributed to positive shifts in family law, it is contended in this article that social science literature has also been employed in ways that decontextualise or misunderstand mothers who have experienced domestic or family violence. ${ }^{\text {iii }}$

In 2006 two key concepts were introduced into the Family Law Act 1975 (Cth) ('FLA'): the best interests of children require maintaining a 'meaningful relationship' with both parents after family breakdown; and children should be kept physically and psychologically safe. Less than one year later these concepts were described as 'twin pillars' in Mazorski v Albright (2007). This article proposes that these pillars have crystallised into two contradictory and parallel narratives that impact negatively on mothers and children where the mothers' evidence of abuse in the family is not believed.

The first narrative - that shared care is desirable - is underpinned by a body of social science research about the impact of parental separation on children and the importance of fathers (eg. Amato and Gilbreth 1999; Hawthorne and Lennings 2008). This literature has been harnessed by father's rights groups (Kaye and Tolmie 1998; Graycar 2012) and found purchase in legislative reforms in 1996 and 2006. It is bolstered by some of the shared care literature, although this scholarship is both highly contested (Rathus 2018) and more nuanced than represented. For example, Elizabeth et al (2010) note that contact with both parents is 
less important for child well-being than exposure to conflict and strong parenting. The second narrative - that children should be protected from family violence and abuse - is also supported by a large body of research that has exposed their many forms, including nonphysical abuse, and their impacts upon children. In Australia much of the best-known research is in the form of government commissioned reports (eg. Queensland Domestic Violence Taskforce 1988, ALRC $2010^{\text {iv }}$ ), although significant feminist work contributed to the growing knowledge base as well (eg. Scutt 1983). This research, and the efforts of women's and children's advocates, have also informed legislative reforms, insistently pressing for safety to be prioritised. Despite sincere endeavours by governments, the family courts and other system actors to respond effectively to family violence, many evaluations and research projects have reported that violence and abuse in the family is sometimes poorly dealt with and that victims of family violence do not feel heard or protected (eg. Dewar and Parker 1999; House of Representatives 2017). In this paper I argue that these two contradictory narratives facilitate the mobilisation of the concept of 'parental alienation' against mothers and children.

It is impossible to provide a concise definition of 'parental alienation' (PA) or 'parental alienation syndrome' (PAS) because of its contested position in scientific and legal literature (Warshak 2015; Meier 2009; Introduction this issue). It is employed by some professionals to describe parental conduct in separated families where the children are, apparently without good reason, reluctant or resistant to spending time with one parent. Whatever its various meanings, this concept has an undoubted existence in Australian family law jurisprudence.

PA is the embodiment of the intersection of social science and family law. It is a social science concept that only occurs in circumstances of parental separation and legal dispute. These families become clients of the family system and have interactions with all of 
its processes and actors. They are surrounded by lawyers, experts and judges who advise on and determine the shape of their post-separation family (Elizabeth 2020). This article interweaves legal and social science scholarly literature, government and other commissioned reports, conference papers, cases and legislative change (see also Doughty et el. 2020), revealing ongoing problems for a mother who makes allegations of violence and abuse, and is not believed, or whose allegations are seen as exaggerated. This mother exists at the very epicentre of the tension between the twin pillars. She may not be permitted to negotiate or litigate as a protective parent within the narrative of child safety. Her efforts to protect are interpreted as obstructive - colliding with the narrative of shared parenting. Her children are not considered unsafe, or are considered safe enough. As a consequence, the father becomes a victim and the mother an abuser, denying her children their rightful relationship with their father.

\section{The early years: 1989 to 1994}

PA first entered the consciousness of the family law community in Australia through a 1989 article, "Brainwashing in Custody Cases: The Parental Alienation Syndrome" in Australian Family Lawyer by forensic psychologist, Kenneth Byrne. This journal was, and still is, widely disseminated among judges, lawyers, social scientists and other family law professionals. The article reported favourably on publications by Richard Gardner, who coined the term 'parental alienation syndrome' using very controversial premises (Introduction). Byrne suggested that, while 'some' claims of child abuse in custody cases 'are legitimate; many more are manifestations of [parental alienation syndrome] embedded in charges of abuse' (1989, p. 3). He also warned solicitors to 'maintain a healthy degree of scepticism' when dealing with a parent who wants to reduce or eliminate contact. 
Byrne carefully wrote in gender neutral language. However, PAS was presented without critique and lawyers were invited to interpret reluctance of children to attend, or of parents to facilitate, contact visits as a likely manifestation of alienation, rather than to explore, or believe, client allegations of abuse by the other parent. Byrne's message was largely aimed at mothers who, in 1989, were the vast majority of custodial parents. Byrne also presented at the National Family Court Conference in 1990 - an internal event attended by Australian judges and other court personnel - thereby delivering his views into the heart of the system.

PAS was not mentioned in an official document until six years later in the report of an Inquiry into complex contact cases (ALRC 1995). Men complained in submissions that 'some custodial parents intimidate and brainwash the children to refuse contact or to be distressed by it', arguing that such behaviour should be considered 'a form of psychological child abuse' (ALRC 1995, para 2.39). The Inquiry was told by others that custodial parents' actions were often 'very understandable' and born out of 'genuine and reasonable fear of violence and abuse to themselves or their children' (ALRC 1995, para 2.40). The idea that 'alienating' children from a parent constitutes child abuse is an on-going motif in the rhetoric of fathers' rights groups (Lapierre et al 2020).

\section{The child's 'right to contact': 1995 to 2005}

By the mid-1990s a synergy was emerging between the rhetoric of fathers' rights groups and messages emanating from the social sciences dominating family law discourse in Australia and elsewhere (Fineman 1991). Lobbying by fathers' rights groups about the importance of fathers and the fairness of joint custody arrangements influenced the shape of both the 1996 and 2006 amendments (Graycar 2012). The Family Law Reform Act 1995 (Cth), effective in 1996, legislated for children to have a 'right of contact' with both parents 
after separation, although, for the first time, the reforms also explicitly recognised 'family violence' as a matter relevant to the best interests of children. Thus began the contradictory, parallel trajectories with potentially competing emphases on continuing relationships and protection from harm.

\section{The first cases}

The first published cases using either the term 'parental alienation' or 'parental alienation syndrome' appeared in published decisions of the Family Court of Australia at the time of these amendments (see Rathus 2016). ${ }^{\mathrm{v}}$ A trio of cases using the term 'parental alienation syndrome' occurred in 1995, 1996 and 1997 and Kenneth Byrne was linked to the latter two. He was an expert witness in the 1996 case - called by the father to cast doubt on allegations of sexual abuse against him - demonstrating an early, but unsuccessful, example of allegations of PA in response to allegations of sexual abuse $(M v H)$. In the 1997 case, Byrne's 1989 article was cited to support the father's successful appeal, allowing him to recall the family report writer for the purposes of cross-examination about PA (Johnson $v$ Johnson). In these early judgments there was no discussion of any critique of PA.

\section{Research}

Various analyses of the 1996 FLA reforms were conducted in the late 1990s and early 2000s (Brown 1998; Dewar and Parker 1999). Research showed that the idea of the implacably hostile mother who was obstructing the key objective of the 1996 amendments was taking hold. Helen Rhoades (2002) explained that the 'no contact' mother had become the 'bad' mother of Australian family law. However, her examination of contact enforcement files from 1999 revealed that mothers accused of contravening orders were actually concerned about the father's parenting capacity and risks of family violence or child abuse, 
and the contact dispute was often a continuation of pre-separation abuse. At the extreme end this discursive strategy was couched in terms of PAS (2002, p. 74).

Another study found that most of the mothers interviewed were 'initially willing to facilitate contact, even when there had been a history of domestic violence' (Rhoades et al. 2000, p.71). Orders for 'no contact' were rarely made - and rarely sought - because solicitors advised clients that they may be perceived as 'hostile' mothers if they pursued such orders (Barnett 2019). Similar advice continues to be a feature of the Australian family law system (Chisholm 2009), with any whisper of hostility said to potentially jeopardise a mother's 'residence' parent role or even contact with her children. Such fears silence women about violence in the family and require them to relinquish their instinct to act protectively. Instead they are cast into the shared care narrative where they will be expected to encourage contact with the father.

Sandra Berns conducted the only socio-legal study in Australia during the 1995 2005 period on PA in 2000-01. She wanted to probe the 'foundational myth' of the 'vengeful former wife' who deliberately 'denigrates the father to the children' and tries to 'frustrate contact'. Berns proposed a possible counter myth of a 'protective and devoted mother, an exemplary parent, seeking to protect her children from a sexually predatory former husband' (2001, pp. 3-4). She found that both myths played out. According to Berns' definitions, all of the alienation cases against the fathers $(n=14)$ were substantiated by the court, whereas only nine of 17 against the mothers were. In eight of the cases where the court held there was alienation by the mother, the fathers' claims had been raised in response to allegations of sexual abuse of the children by the father. The success of alienation claims raised by fathers in response to child sexual abuse claims by mothers recurs through this history (see also Meier 2020). Berns' research led her to tentatively conclude that fathers used PA more as a 
tactic than mothers - some were 'obsessed alienators and PAS was part of a pattern of abusive and controlling behaviour following separation' (2001, p. 16).

Rae Kaspiew (2005) also found that PA operated in a gendered way. Fathers positioned mothers' concerns about contact as stemming 'from a deviant, anti-father attitude', undercutting the overall philosophy of the reforms (Kaspiew 2005, p. 145). Notwithstanding fathers' violence, control and denigration, it was the mothers' attitudes towards the fatherchild relationships that came under scrutiny. Again, fathers emerged as victims - and pushed a narrative that required mothers to facilitate contact.

\section{More cases}

After the first three published decisions in which 'parental alienation syndrome' appeared (between 1995 and 1997), it next appeared in a published case in 2001. In $P v D$ Justice Lindenmayer accepted the opinion of an expert psychiatrist who based his views on the work of Gardner (1985). His Honour found that 'the situation was one of 'classical parental alienation', ( $P \vee D$, para. 102) but was openly appalled by the father's brutal campaign of harassment against the mother:

The sorts of insults which he directed at the mother, in a tone and manner no doubt dripping with hatred and loathing, could not fail to wound her so deeply that the scars will never disappear. It is little wonder that the woman who was the victim of such a sustained campaign of vilification would want to prevent the perpetrator of that attack from having any influence over her child ( $P v D$, para. 455.6 (iii)).

Despite this frank assessment of the capacity of the father to inflict emotional hurt, the judge accepted the expert's evidence that there could be long term serious adverse consequences for the nine-year-old boy if he continued to live with his mother without contact with his father $(P \vee D$, para. 435). Based on the expert's recommendations, his 
Honour ordered a change of residence to the father, even though he retained 'reservations about [the father's] capacity to cope with the sort of problems which [the son] and he would undoubtedly experience' ( $P$ v $D$, para. 455.7(iv)).

PAS was then a new social science idea in the courts; the early published cases contain no accompanying critique. The emphasis on the child's right to contact gave this new idea a direct effect - it cast scrutiny onto the attitude of the parent who was not willingly fulfilling the narrative of maintaining relationships and submerged the relevance of the reasons for that attitude.

The rapid transference of information in the family law community emerged in a case heard in August 2004 that questioned the legitimacy of PAS, where judgment was reserved. Later that year social scientist Janet Johnston presented a paper, "Children of Divorce Who Reject a Parent and Refuse Visitation: Recent Research and Social Policy Implications for the Alienated Child", at the Australian National Family Law Conference in which she discussed many 'problems' with PAS (2004, p. 221). Handing down his judgment in March 2005, Judicial Registrar Ramsden noted that, although in 1997 the Full Court had accepted that PAS fell within 'a substantially established area of knowledge', (Summers $v$ Nathan, para. 57), he had perused the work of Johnston and others:

In the light of these articles and a large body of recent literature, I am not persuaded immediately that "P.A.S." has been established irrevocably as being within a substantially established area of knowledge allowing for the receipt of expert evidence (Summers v Nathan, para. 63)

So began some scepticism about the idea of PAS in the Australian family courts.

\section{More legislative change ahead}


But family law was about to change again. The 1996 reforms had not appeased fathers' rights groups and their further lobbying led to a highly charged Parliamentary Inquiry in 2003. The Inquiry centered on whether there should be a presumption of 'equal time' for both parents in post-separation children's arrangements (House of Representatives 2003). The Report from the Inquiry did not discuss PA directly.

A long process of public consultations followed the report until an Exposure Draft of an Amendment Bill was released in 2005. A 'number of submissions' to the Parliamentary Committee considering this document suggested that parental conduct to alienate a child from the other parent 'should be included in the definition of abuse' (House of Representatives 2005, para. 2.114). That idea was not acted on, but other submissions from organisations linked to fathers' rights groups urged the view that mothers make false allegations of abuse to prevent fathers from having relationships with their children. ${ }^{\mathrm{vi}}$

\section{The presumption of shared parenting: 2006 to 2012}

Although a presumption of equal time was not ultimately legislated, the package of amendments that came with the Family Law Amendment (Shared Parental Responsibility) Act 2006 (Cth) was touted as a 'bold new reform agenda' and 'cultural shift' in family law (House of Representatives 2004-2005). The changes included: a rebuttable presumption that the best interests of children require parents to have equal shared parental responsibility; a 'primary consideration' in the best interest factors that children should have the 'benefit' of a 'meaningful relationship' with both parents; and a 'friendly parent' provision. ${ }^{\text {vii }}$

\section{Reports and research}

After the amendments at least seven evaluations and reports were commissioned by the government (Chisholm 2009; Family Law Council 2009; Kaspiew et al. 2009; Bagshaw et al. 2010; Cashmore et al. 2010; McIntosh et al. 2010; ALRC 2010). This period signalled 
the entry of Australian researchers into a quite virulent debate in the international socio-legal literature about shared care arrangements, particularly for young children. Elizabeth et al. neatly problematised the impact of the shared care ideology on mothers in New Zealand at this time, showing how easily they could be labelled hostile, even after a long history of endeavouring to facilitate contact with fathers (Elizabeth et al. 2010).

Only one of the reports (Bagshaw et al. 2010) made specific mention of PA in research commissioned to examine the impact of family violence on post-separation parental decision-making. Many mothers who completed an online survey said that the violence they had experienced 'was difficult to prove, in particular when the abuse was not physical' (Bagshaw et al. 2010, p. 84). They 'were often disbelieved by professionals in the family law arena, in spite of providing evidence' (Bagshaw et al. 2010, p. 84), and were thus pushed out of the protective parent category. In contrast, fathers complained that they were 'falsely accused of being violent or abusive to their children' (Bagshaw et al. 2010, p. 84). One suggested that his child 'suffered from the parent alienation syndrome and was possibly hypnotised by my ex's friend' (Bagshaw et al. 2010, p. 88).

Other research published in 2010 showed the powerful influence of PA well before litigation commenced. A collaboration between women's domestic violence services and Lesley Laing (2010) involved interviews with 22 women, some of whom reported being accused of alienation even where there was a proven history of assault. Again, women described receiving advice from lawyers and domestic violence workers about the risks of raising allegations of violence and abuse because they would be seen as alienating (Laing 2010, pp. 10 and 55; Elizabeth 2020; Collective Backbone 2019).

Writing extra-judicially, Tom Altobelli acknowledged that 'disconcerting complexity' is involved where children appear to reject one parent but, 'from a strictly legal perspective', such conduct clashes with the overarching philosophy of the FLA of the importance of 
ongoing relationships (2011, p. 185). In his words, such conduct 'strikes at the heart of the principles of shared parenting' and 'the root of the child's meaningful relationship with one parent' (2011, p. 185). This strong language underscores the problems that beset mothers who fear for their children's safety on contact or whose children are reluctant to spend time with their fathers.

\section{Family violence reforms: 2012 to 2018}

After receiving the multiple reports on the 2006 amendments, and partly in response to a tragic family homicide in $2012,{ }^{\text {viii }}$ the government undertook another tranche of reforms specifically intended to achieve 'better protection for children and families at risk of violence and abuse' (House of Representatives 2010-11, p. 1). The Family Law Legislation Amendment (Family Violence and Other Measures) Act 2011 (Cth) became operative in 2012. Despite a new definition of 'family violence' and some legislative tinkering, the contradiction between maintaining relationships and protecting children was unresolved (Rathus 2013; Strickland and Murray 2014). In this final era (2012 to 2018), discussion about PA continued at conferences, in some academic research, in commissioned and community reports and in cases. 


\section{Conferences}

At the 2013 World Congress on Family Law and Children's Rights in Sydney, Vincent Papaleo presented a paper on PA. Papaleo is a well-known Australian clinical psychologist in private practice who presents at many conferences and writes family reports. His paper considered PA in depth but made only one reference to family violence in connection with 'feminist groups' who 'dismiss all or most alienation claims as fabrications made by male perpetrators of intimate partner violence' as a further exertion of control (Papaleo 2013, p. 1; see also Meier 2020). Although Papaleo accepted that some men alienate their children from their mothers, and that there are children who reject a parent for good reason, women were given special attention as alienators in his presentation:

... there are some women who consciously or unconsciously, be they motivated by vengeance or due to psychological vulnerabilities, actively alienate their children from fathers with whom previously, the children had at least a good enough relationship. It is also true that a subset of these women may make repeated false allegations of abuse and some may do so intentionally, whilst others may do so unintentionally, truly believing what they say, and never being reassured by an investigative process that does not confirm that abuse did not occur (Papaleo 2013, p.3) [emphasis added].

With these words, Papaleo invited professionals to conceptualize the father-client as the victim of a vengeful ex-wife (Berns 2001) or of false sexual abuse allegations (Byrne 1989). And like Byrne, he had the attention of members of the family law community.

During the subsequent discussion of his model of clinical intervention there was no mention of family violence or child abuse. It seems possible that, for those intervening clinically in these families, once PA has been determined, violence or abuse disappears, or becomes irrelevant, because otherwise there would be no PA and no clinical intervention. 
In 2018 the Australian Chapter of the Association of Family and Conciliation Courts held a conference in Adelaide entitled 'Alienation? Myths, Complexities and Possibilities ....' For his paper Nicholas Bala (2018) used broad search terms ${ }^{\text {ix }}$ to identify 100 Australian 'alienation' cases between 2012 and 2018. According to Bala, domestic violence was an issue in 60 of the cases. In 34 of those the court found that there was domestic violence and therefore no PA. However, in the other $26(43 \%)$, the violence was found to be mutual, 'historic, not serious enough or unfounded' (Bala 2018, slide no. 29). Also, consistent with the history outlined in this article, his study showed that sexual abuse allegations were often hard to sustain and $20(87 \%)$ of the 23 alleged cases were considered unfounded. These numbers suggest there is a significant proportion of cases in the family law system where allegations of abuse by victims, or parents of victims, have been disbelieved or dismissed.

\section{More research and reports}

Research by Jodie Death and others (2019) considered a cohort of cases involving allegations of child sexual abuse $(n=357)$ between 2010 and 2015, identifying $44(12.3 \%)$ that contained references to alienation. They reported that, although Australian family courts are 'willing to acknowledge PA relatively often' (Death et al. 2019, p. 8), complete exclusion of the alleged alienator from the lives of the children was not common. Orders for equal shared parental responsibility were made in most of the cases and a change of residence to the father was only ordered in six.

This study found that generally Australian family courts made a 'genuine effort' to acknowledge the trauma of parental conflict on children and are less punitive in their approach than some other jurisdictions. However, where PA is raised 'as an explanation for allegations of [child sexual abuse]', the judgments reveal the hostile environment the court process must represent for the women. Consistent with other research covered in this article, 
the court still relied on the 'gendered discourses of hysterical, vindictive and manipulative women that have historically been used to discredit women and children' (Death et al. 2019, p. 8).

Although some official reports since the 2012 amendments do not refer to PA per se, complaints by fathers that mothers make false allegations of abuse have continued, and mothers relate that they are advised not to raise a history of violence for fear they will be disadvantaged in parenting proceedings (House of Representatives 2017, pp. 52-54). A participant in community-based research by Bravehearts Foundation poignantly exposed the synergy between fathers' rights' claims and PA allegations:

I was seen as a mother who wanted to alienate the child's father. One magistrate told me that my daughter would become promiscuous if she didn't have a relationship with her father (Bravehearts 2016, p. 171).

\section{A case}

A 2016 case (and the 2017 appeal) demonstrate that this history repeats in the courts. The case has many echoes of $P v D$ from 2001. In Ralton $v$ Ralton there was again a nineyear-old boy who was resistant to contact with his father. Again, residence was transferred from the mother to the father despite judicial acknowledgement 'that there would be considerable grieving in the short term' (Ralton $v$ Ralton [2016] para. 119). The unrepresented mother believed she must fight the alienation accusation raised in the family report, and obtained a psychiatric report that described difficulties with the PAS concept. But, 15 years after $P v D$, judges are more attuned to the scientific contestation and nuanced in their approach. Judge Riethmuller sidelined the expert report, saying: 
... to become focused upon the academic discussion of alienation and whether or not it is a syndrome - and it seems clear that it is not - becomes more of a distraction than anything in this individual case (Ralton $v$ Ralton [2016] para. 70).

His Honour said that he would analyse the evidence to ascertain what was in the children's best interests, but the mother's attitude towards the father was central to the final decision. The court found that the boy [and his less affected sister] were 'at risk of longerterm psychological harm in the mother's household' (Ralton v Ralton [2016] para. 144) because she would not facilitate a relationship with the father.

The judge's rejection of the language of alienation enabled the appellate court to say that there was 'no need for us to consider whether or not the evidence justified a finding of parental alienation', nor whether it is a valid concept (Ralton $v$ Ralton [2017] para. 192). PA was rendered technically inapplicable in a case where the concept was central. As noted by Elizabeth (2020), the 'spectre' of PA looms large.

\section{Conclusion}

Where stands Australia in 2019? In March the Australian Law Reform Commission released (yet another) review of the family law system. Critical aspects of the legislation remain unchanged. Two principles proposed for a new list of best interests factors continue the tension between maintaining relationships and child protection: what arrangements best promote the safety of the child and the child's carers, including safety from family violence, abuse, or other harm; and the benefit to the child of maintaining relationships with each parent and others who are significant to the child, where it is safe to do so (ALRC 2019, p. $165)$.

Although the word 'meaningful' has not been retained in these principles, reliance on the 'benefit' of ongoing child-parent relationships continues. Despite efforts to deal better 
with family violence and sexual abuse, some mothers and their children will be pushed into the shared parenting narrative when their accounts of violence and abuse are disbelieved, minimised or silenced.

Unfortunately, women who have suffered trauma can be unconvincing witnesses (Mack 1993), no matter how accurate their disturbing evidence. There may be mothers who have misconstrued fathers, believing them more dangerous than they are, and some who may be lying or exaggerating. But where mothers or children are truthful and accurate, yet unable to convey this truth, the consequences of disbelief or dismissal can be devastating for them. These truth-tellers are still at risk of being perceived as Byrne's 'brainwashers', Berns' 'vengeful' former wives or Rhoades' 'bad' mothers.

In 1989 Kenneth Byrne warned lawyers to 'maintain a healthy degree of scepticism' when working with a parent who wants to reduce or eliminate the other parent's contact with their children. Perhaps, rather, history shows that all actors in the system should 'maintain a healthy degree of scepticism' when one parent makes a claim of alienation against the other and carefully consider all of the reasons why the children may be resistant to spending time with the rejected parent. 


\section{REFERENCES}

Altobelli, T., 2011. When a Child Rejects a Parent: Why Children Resist Contact. Australian Journal of Family Law, 25 (3) 185-209.

Amato, P. and Gilbreth, J.G., 1999. Non-Resident Fathers and Children's Well-Being: A Meta-Analysis. Journal of Marriage and Family, 61 (3), 557-573.

Australian Law Reform Commission (ALRC), 1995. For the Sake of the Kids: Complex Contact Cases and the Family Court. Canberra: Commonwealth of Australia. Report Number 73.

Australian Law Reform Commission (ALRC), 2010. Family Violence: A National Legal Response: Final Report. Canberra: Commonwealth of Australia. Report Number 114. Australian Law Reform Commission (ALRC), 2019. Family Law for the Future - An Inquiry into the Family Law System. Canberra: Commonwealth of Australia.

Bagshaw, D., et al., 2010. Family Violence and Family Law in Australia: The Experiences and Views of Children and Adults from Families who Separated Post-1995 and Post 2006. Melbourne: Monash University.

Bala, N., 2018. Parental Alienation: Social Context and Legal Resources. In: Alienation? Myths, Complexities and Possibilities..., 5th Annual AFCC Australian Chapter Conference August 2018, Adelaide.

Berns, S.S., 2001. Parents Behaving Badly: Parental Alienation Syndrome in the Family Court - Magic Bullet or Poisoned Chalice. Australian Journal of Family Law, 15, 1-24. Bravehearts Foundation, 2016. Abbey's Project: A Bravehearts Paper on the Family Law System. Arundel, Qld: Bravehearts Foundation.

Brown, T., et al., 1998. Violence in Families: Report No. 1: The Management of Abuse Allegations in Custody \& Access Disputes Before the Family Court of Australia. Melbourne: Monash University.

Byrne, K., 1989. Brainwashing in Custody Cases: The Parental Alienation Syndrome. Australian Family Lawyer, 4 (3), 1.

Cashmore, J., et al., 2010. Shared Care Parenting Arrangements Since the 2006 Family Law Reforms: Report for Australian Government Attorney-General's Department. Sydney: Social Policy Research Centre, University of New South Wales. 
Chisholm, R., 2009. Family Courts Violence Review. Canberra: Attorney-General's Department.

Death, J., et al., 2019. Parental alienation, coaching and the best interests of the child: Allegations of child sexual abuse in the Family Court of Australia. Child Abuse \& Neglect, 94, 104045-104054.

Dewar, J. and Parker, S., 1999. The Impact of the New Part VII Family Law Act 1975. Australian Journal of Family Law, 13, 1-21.

Doughty, J and Maxwell and Slater (I DON'T KNOW THEIR NAMES) Professional responses to 'parental alienation': Research-informed practice. Journal of Social Welfare and Family Law, 42 (1).

Elizabeth, V., Gavey, N. and Tolmie, J., 2010. Between a Rock and a Hard Place: Resident Mothers and the Moral Dilemmas They Face During Custody Disputes. Feminist Legal Studies, 18:253-274.

Elizabeth, V., 2020. The affective burden of separated mothers in PA(S) inflected custody law systems: A New Zealand case study. Journal of Social Welfare and Family Law, 42 (1).

Family Law Council, 2009. Improving Responses to Family Violence in the Family Law System: An Advice on the Intersection of Family Violence and Family Law Issues. Canberra: Commonwealth of Australia.

Fineman, M., 1991. The Illusion of Equality: The Rhetoric and Reality of Divorce Reform. University of Chicago Press.

Gardner, R. A., 1985. Recent Trends in Divorce and Custody Litigation. Academy Forum, 29 (2), 3-7.

Graycar, R., 2012. Family Law Reform in Australia, or Frozen Chooks Revisited Again?. Theoretical Inquiries in Law, 13 (1), 241-269.

Hawthorne, R. and Lennings, C., 2008. The Marginalization of Non-Resident Fathers: Their Postdivorce Roles. Journal of Divorce \& Remarriage, 49 (3), 191-209.

House of Representatives, 2003. Every Picture Tells a Story: Report on the Inquiry into Child Custody Arrangements in the Event of Family Separation. Canberra: Parliament of the Commonwealth of Australia. 
House of Representatives, 2004-2005. Explanatory Memorandum Family Law Amendment (Shared Parental Responsibility) Bill 2005. Canberra: Parliament of the Commonwealth of Australia.

House of Representatives, 2005. Report on the exposure draft of the Family Law Amendment (Shared Parental Responsibility) Bill 2005. Canberra: Parliament of the Commonwealth of Australia.

House of Representatives, 2010-11. Explanatory Memorandum Family Law Legislation Amendment (Family Violence and Other Measures) Bill 2011. Canberra: Parliament of the Commonwealth of Australia.

House of Representatives, 2017. A Better Family Law System to Support and Protect Those Affected By Family Violence: Recommendations For An Accessible, Equitable and Responsive Family Law System Which Better Prioritises Safety of Those Affected By Family Violence. Canberra: Parliament of the Commonwealth of Australia.

Johnston, J., 2004. Children of Divorce Who Reject a Parent and Refuse Visitation: Recent Research and Social Policy Implications for the Alienated Child. In: 11th National Family Law Conference, Broadbeach, Queensland.

Kaspiew, R., 2005. Violence in Contested Children's Cases: An Empirical Exploration. Australian Journal of Family Law, 19 (2), 112.

Kaspiew, R., et al., 2009. Evaluation of the 2006 Family Law Reforms. Melbourne: Australian Institute of Family Studies.

Kaye, M. and Tolmie, J., 1998. Fathers' Rights Groups in Australia and Their Engagement With Issues in Family Law. Australian Journal of Family Law, 12 (1), 19-69.

Laing, L., 2010. No Way to Live: Women's Experiences of Negotiating the Family Law System in the Context of Domestic Violence. New South Wales Health, University of Sydney and Benevolent Society

Lapierre, S., Ladouceur, P., Frenette, M. and Côté, I., The Legitimization and Institutionalization of 'Parental Alienation' in the Province of Quebec Journal of Social Welfare and Family Law, 42 (1).

Mack, K., 1993. Continuing Barriers to Women's Credibility: A Feminist Perspective on the Proof Process. Criminal Law Forum, 4 (2) 327-353. 
McGhee, A., 2015. Darcey Freeman inquest: Doctors knew father who threw 4yo off Melbourne's West Gate Bridge was violent, court hears. ABC News Online, 16 July 2015.

McIntosh, J., et al., 2010. Post-Separation Parenting Arrangements and Developmental Outcomes for Infants and Children - Collected Reports. North Carlton, Victoria: Family Transitions.

Meier, J.S., 2009. A Historical Perspective on Parental Alienation Syndrome and Parental Alienation. Journal of Child Custody, 6, 232-257.

Meier, J. 2020. (WERE THERE OTHERS IN THIS?) U.S. child custody outcomes in cases involving parental alienation and abuse allegations: What do the data show? Journal of Social Welfare and Family Law, 42 (1).

Papaleo, V., 2013. When Children Refuse Contact with a Parent - The Language of Conflict and the Reciprocal Relationship Between the Court and The Social Sciences. In: 6th World Congress on Family Law and Children's Rights May 2013, Sydney.

Queensland Domestic Violence Task Force, 1988. Beyond These Walls: Report of the Queensland Domestic Violence Task Force to the Honourable Peter McKechnie, M.L.A., Minister for Family Services and Welfare Housing. Brisbane: Department of Family Services.

Rathus, Z., 2013. Shifting language and meanings between social science and the law: Defining family violence. University of New South Wales Law Journal, 36 (2) 359.

Rathus, Z., 2016. Mapping the Use of Social Science in Australian Courts: The Example of Family Law Children's Cases. Griffith Law Review, 25 (3), 352-382.

Rathus, Z., 2018. 'The Research Says ... ': Perceptions on the Use of Social Science Research in the Family Law System. Federal Law Review, 46 (1), 85-111.

Rhoades, H., et al.,2000. The Family Law Reform Act 1995: The Frist Three Years. University of Sydney.

Rhoades, H., 2002. The No Contact Mother. International Journal of Law, Policy and the Family, 16, 71-94.

Robertson, L. and Broadhurst, K., 2019. Introducing Social Science Evidence in Family Court Decision-Making and Adjudication: Evidence from England and Wales. International Journal of Law, Policy and the Family, 33 (2), 181-203. 
Scutt, J.A., 1983. Even in the Best of Homes: Violence in the Family. Ringwood, Victoria: Pelican Books.

Strickland, S., and Murray, K., 2014. A Judicial Perspective on the Australian Family Violence Reforms 12 Months On. Australian Journal of Family Law, 28, 47.

Warshak, R., 2015. Parental Alienation: Overview, Management, Intervention, and Practice Tips. Journal of the American Academy of Matrimonial Lawyers, 28, 181-248.

\section{Cases}

Johnson v Johnson [1997] FamCA 32

$M v H[1996]$ FamCA 42

Mazorski v Albright [2007] FamCA 520

$P v D[2001]$ FamCA 1197

Ralton v Ralton [2016] FCCA 1832

Ralton v Ralton [2017] FamCAFC 182

Summers $v$ Nathan [2005] FamCA 1406

\section{Legislation}

Family Law Act 1975 (Cth)

Family Law Amendment (Shared Parental Responsibility) Act 2006 (Cth)

Family Law Legislation Amendment (Family Violence and Other Measures) Act 2011 (Cth)

Family Law Reform Act 1995 (Cth) 
My thanks go to my friends and colleagues: Mary Keyes, Kylie Burns, Molly Dragiewicz, Heather Douglas and Nali Wardill and to Nicholas Bala, who generously provided me with the raw data for his presentation in Australia at the 2018 AFCC, Australian Chapter conference.

i The term 'parenting cases' is used in Australia whereas other jurisdictions use 'custody' or 'children's cases'.

ii eg, mandatory pre-filing form of mediation. I HAVE TO COMMENT ON THESE FOOTNOTES IN THIS MANNER BECAUSE I CANNOT ADD COMMENTS TO THEM. IS THIS ABOUT A FORM (PAPER OR ELECTRONIC) THAT HAS TO BE COMPLETED BEFORE FILING IS ALLOWED, OR DOES IT REFER TO A SPECIFIC METHOD OF MEDIATION? IF THE FORMER, MIGHT IT BE CLEARER AS "E.G. THE NEED TO FILE A FORM RELATING TO MEDIATION BEFORE A CASE CAN BE ISSUED"? IF THE LATTER, PERHAPS "E.G. MANDATORY UNDERTAKING OF A SPECIFIC TYPE OF MEDIATION" IT IS THE LATTER AND SHOULD PERHAPS SAY "E.G. MANDATORY ATTENDANCE AT A TYPE OF MEDIATION BEFORE PROCEEDINGS CAN BE FILED, ALTHOUGH THERE ARE EXCEPTIONS TO ATTENDANCE."

iii This article uses 'family violence' to describe intimate partner violence and other violence in the family. iv 'ALRC' refers to the Australian Law Reform Commission.

v This was ascertained by searching for the terms 'parental alienation' and 'parental alienation syndrome' on the free online case data base AUSTLII. All possible family courts were searched - the Family Court of Australia, Full Court of Family Court, Federal Magistrates Court, Federal Circuit Court and Family Court of Western Australia.

${ }^{v i}$ Eg. Submission 1179 from Shane Kelly of the Richard Hillman Foundation, 'Parental Alienation Syndrome and the Family Court in Relation to Joint Parenting', lodged 8 August, 2003. I DON'T THINK THIS DATE OF 2003 CAN BE CORRECT, WHEN THE CONSULTATION REFERRED TO IN THE BODY OF THE PAPER COMMENCED IN 2005.

vii 'Friendly parent' provisions focus on the willingness of parents to facilitate a relationship with the other parent.

viii In 2009 Arthur Freeman threw his four year-old daughter off a bridge in Melbourne in front of her brothers after his contact time was reduced by a family court the previous day (McGhee 2015).

ix 'parent' and 'alienat' within five words of each other. 